\title{
Connessioni digitali. Integrazione dati in ambiente BIM per l'intervento sul patrimonio esistente
}

\author{
Federica Maietti \\ Nicola Tasselli
}

\section{Abstract}

II contributo è incentrato sulla strutturazione di un processo metodologico di acquisizione e integrazione dati per lo sviluppo di strumenti digitali in ambiente BIM (Building information modeling). Tale processo è finalizzato all'ottimizzazione dei processi di digitalizzazione a supporto dell'intervento di riqualificazione, rigenerazione, manutenzione e gestione del costruito esistente. L'ambito della ricerca, attualmente in corso e nelle sue prime fasi di sviluppo, è circoscritto al patrimonio esistente della regione Emilia-Romagna, e fa riferimento al patrimonio 'diffuso' che necessita di essere riqualificato al fine di raggiungere gli attuali standard in materia di sicurezza, efficienza energetica, comfort, ecc. L'integrazione di strumenti digitali e lo sviluppo di procedure in ambiente parametrico attraverso la connessione di dati informativi multilayer, portano alla strutturazione di modelli BIM ad alto valore informativo, integrati e accessibili. Un processo che vede nella digitalizzazione - dal rilievo ad alta densità informativa alla modellazione e condivisione - una possibile risposta in termini di efficientamento del processo.

Parole chiave

Building Information Modeling, patrimonio esistente, rappresentazione, rilievo 3D, riqualificazione.

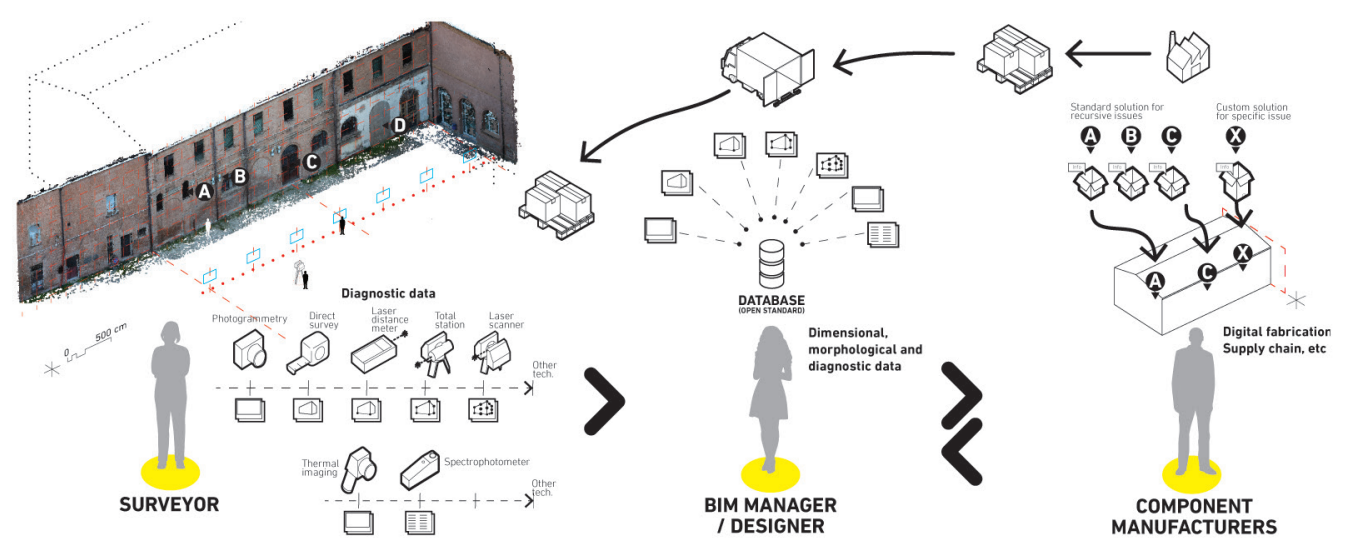


Fig. I. Schematizzazione del flusso di integrazione tra le fasi di rilievo, progettazione e realizzazione dell'intervento sul costruito. La ricerca mira alla definizione di un protocollo che leghi la fase rilievo dell'esistente alla modellazione integrata in ambiente BIM.

\section{Introduzione}

II presente contributo sintetizza un percorso di ricerca che integra diversi aspetti propri della disciplina del Disegno con tematiche fortemente interdisciplinari connesse a una delle esigenze più stringenti nel panorama attuale: la conservazione, riqualificazione e rigenerazione del patrimonio esistente. L'ambito di ricerca è circoscritto, a livello territoriale, alla regione Emilia-Romagna, partendo da una serie di priorità individuate nell'ambito di rapporti di monitoraggio [I] sullo stato di attuazione delle strategie regionali di ricerca e innovazione, che individuano la riqualificazione del patrimonio esistente, la rigenerazione urbana, la qualità architettonica, e l'innovazione tecnologica, progettuale e processuale come temi centrali delle traiettorie tecnologiche per il settore regionale.

Il tema della digitalizzazione dei processi può essere definito una priorità tecnologica, laddove documentazione, rilievo digitale, modellazione e integrazione dati si rendono sempre più necessari nella gestione dell'intervento sul patrimonio esistente.

In tale scenario, la ricerca propone di contribuire allo sviluppo di strumenti digitali in ambiente BIM finalizzato a una maggiore efficienza del quadro degli interventi rigenerativi del patrimonio costruito regionale, la definizione di nuove soluzioni tecnologiche integrate e di protocolli di intervento e di monitoraggio.

Due sono gli obiettivi principali della ricerca. Da un lato l'ottimizzazione del rilievo digitale integrato applicabile alle fasi di documentazione, acquisizione, archiviazione, analisi, gestione e rappresentazione dei dati definendo un protocollo in cui all'acquisizione metrica e morfologica dell'esistente vengono integrati tutti i livelli informativi necessari alla gestione dell'intervento sul costruito esistente.

Dall'altro, l'applicazione della metodologia Building Information Modeling (BIM) all'esistente come sostanziale miglioramento del processo che sottende gli interventi rigenerativi del patrimonio costruito, attraverso la creazione di archivi informatizzati, fruibili dai diversi attori coinvolti nel processo, verso la definizione di nuove soluzioni tecnologiche integrate.

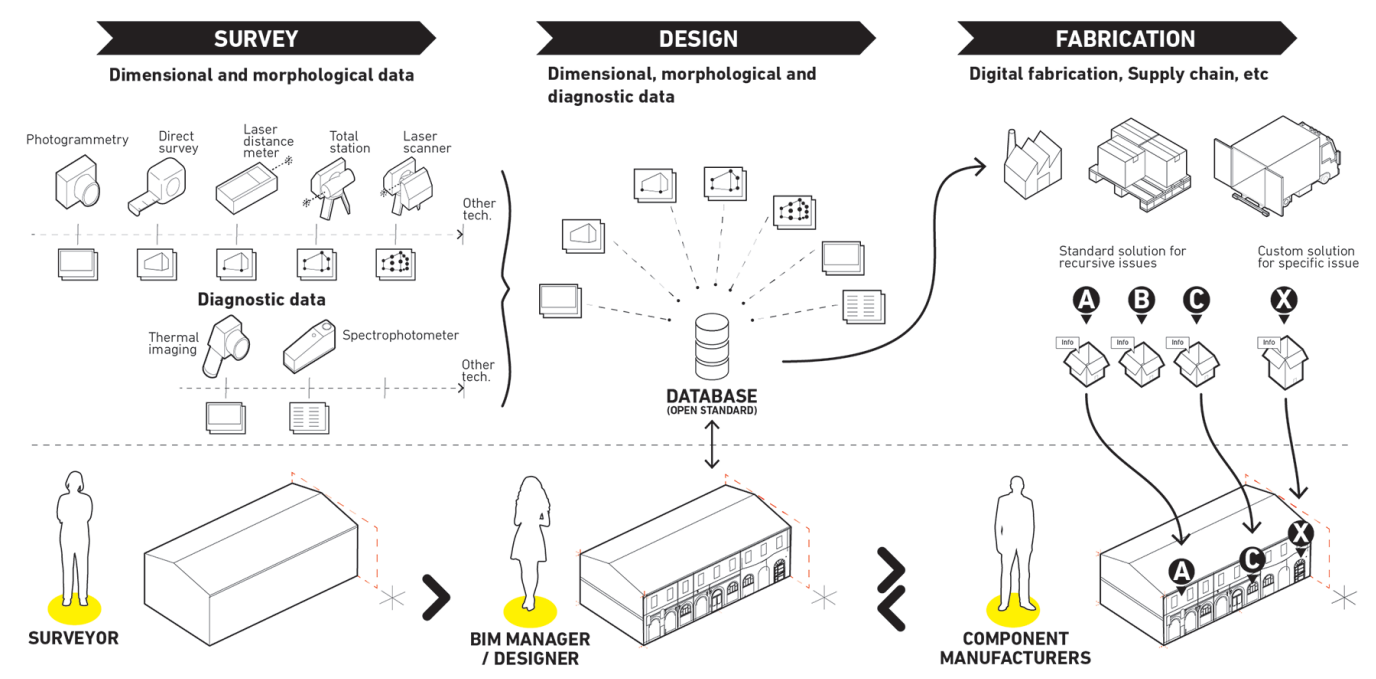

Ambito della ricerca e stato dell'arte

Lo stato dell'arte in materia di digitalizzazione del patrimonio esistente [Bianchini 2014; Brusaporci 2019] e di modellazione parametrica in ambiente BIM [Bianchini, Inglese, Ippolito 20 I6] si configura come un panorama ricco e articolato, in cui la ricerca e le diverse applicazioni spaziano nel fornire contributi sempre più mirati alla risoluzione di diverse criticità [López et al. 2016; Bolognesi, Fiorillo 2019].

Lo sviluppo di nuove tecnologie di rilievo e diagnostica e l'ottimizzazione di tecnologie per l'acquisizione speditiva dei dati [Gallozzi et. al. 2019], lo sviluppo di banche dati accessibili per la documentazione del ciclo di vita del costruito [Apollonio et al. 2019; Tommasi et al. 2019], e, 
più in generale, l'ottimizzazione, standardizzazione e interoperabilità dei processi nella direzione del progetto integrato, rappresentano ambiti di ricerca imprescindibili per la conservazione e valorizzazione del patrimonio costruito, storico e 'diffuso'.

In aggiunta a una gestione più efficiente dell'intervento sul costruito attraverso strumenti digitali integrati, la ricerca si pone l'obiettivo di contrastare l'obsolescenza dei dati digitali (dovuta alla scarsa standardizzazione) favorendo una più efficiente fruizione nel tempo dei dati digitali raccolti e l'interoperabilità [Djuedja et al. 2019] tra sistemi diversi (Open access data). Da un lato la ricerca si propone quindi di ottimizzare la digitalizzazione del costruito esistente, dall'altro di rispondere alla frammentazione del processo e all'inefficiente utilizzo dei dati attraverso la modellazione parametrica, integrando dati informativi di diversa natura (informazioni ottenute nella fase di rilievo, analisi e documentazione) nei modelli BIM (sia di carattere volumetrico/morfologico che tecnologico).

\section{Metodologia applicata}

La ricerca è strutturata in quattro ambiti principali: a partire dalla definizione dello stato dell'arte, l'ottimizzazione di un protocollo di rilievo integrato che consenta l'acquisizione e gestione delle informazioni in funzione della scala e della complessità dell'intervento [Fassi et al. 20 I5] si connette a un'analisi critica delle caratteristiche da implementare nella gestione delle informazioni di rilievo in ambiente parametrico BIM [Osello et al. 20 I6] per lo sviluppo di strumenti/pacchetti informativi di dati integrati a supporto dellintervento sul costruito esistente. L'ultima fase prevede l'applicazione su casi studio individuati in ambito regionale, appartenenti al patrimonio esistente del Novecento caratterizzati da livelli di complessità utili a testare gli strumenti digitali proposti.

Perseguendo il principale obiettivo di favorire lo sviluppo di protocolli di acquisizione e gestione di informazioni (morfologiche e diagnostiche), portando allo sviluppo di strumenti BIM a supporto del progetto di intervento, la ricerca si articola in quattro fasi principali.

L'analisi delle metodologie di rilievo integrato, morfometrico e diagnostico, e lo sviluppo di criteri di acquisizione e gestione dati costituiscono la prima fase, finalizzata all'ottimizzazione delle procedure di acquisizione in funzione delle specifiche esigenze di analisi e intervento sul costruito. In aggiunta alle procedure di rilievo metrico-morfologico ad alta densità informativa, lo studio degli strumenti di documentazione e rilievo diagnostico integrabili nel processo di acquisizione dati è fondamentale al fine di ottenere un modello in cui le informazioni tecnologiche/conservative sono integrate alle informazioni metriche. Si prevede inoltre la strutturazione di un sistema di archiviazione dei dati di rilievo e delle informazioni aggregate (materiali, stato conservativo, documentazione sugli interventi precedenti, ecc.) considerando le diverse tipologie di utenti coinvolti nell'intervento e finalizzata alla strutturazione di una banca dati integrata interoperabile [Logothetis et. al. 20।8]. Tale metodologia di strutturazione dei dati permette la gestione integrata di diverse informazioni, tenendo traccia dei dati sorgente, al fine di poterne verificare l'accuratezza.

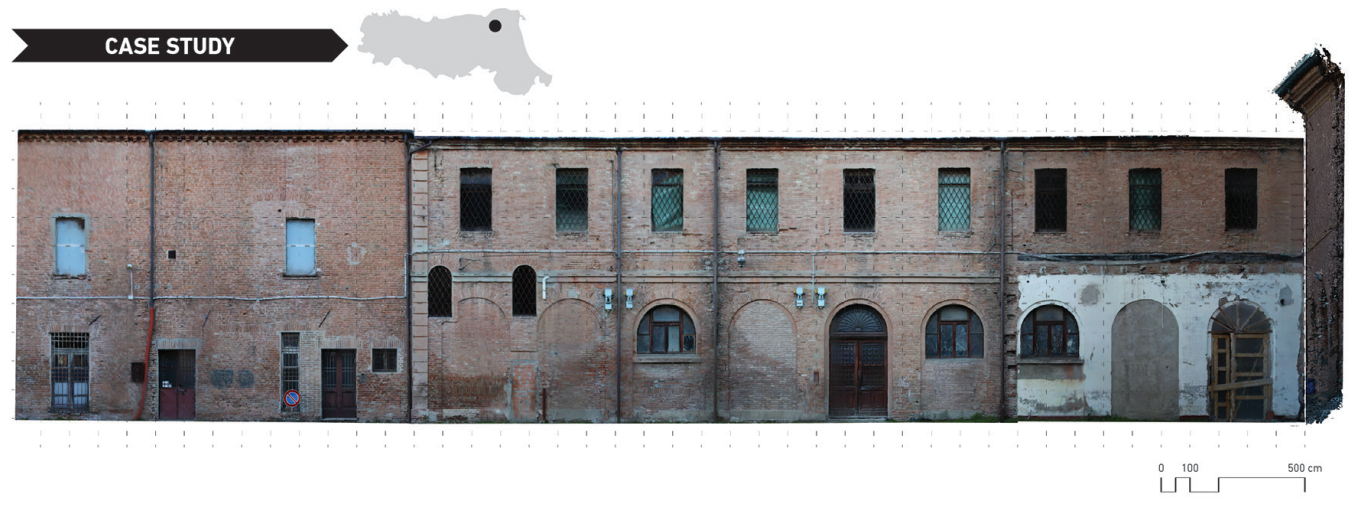




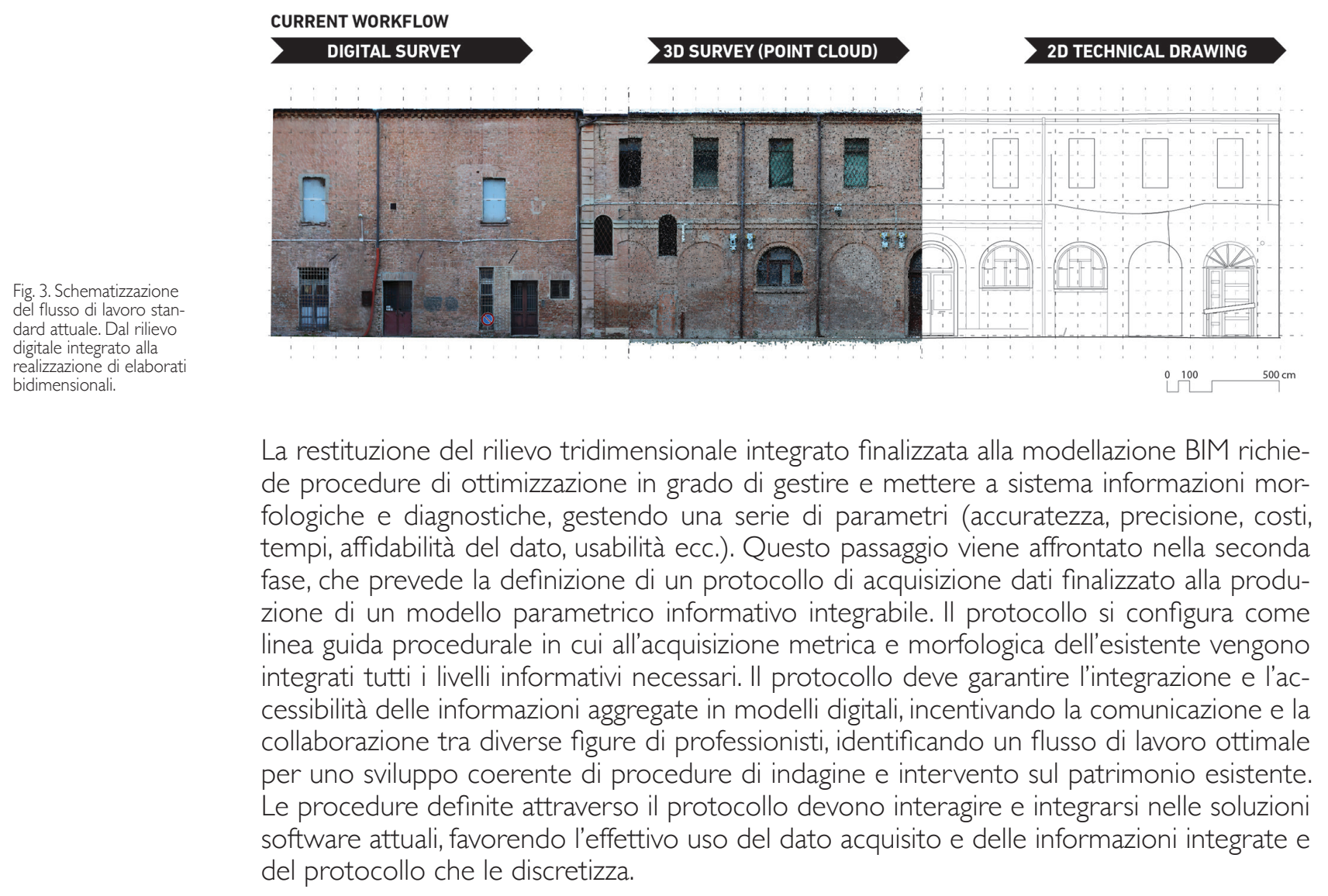


impiegati, le fasi di realizzazione, i costi, le caratteristiche tecniche, ecc. e in cui l'edificio è messo in relazione con fattori ambientali, definendo il L.o.D. (Level of Detail) - L.o.G. (Level of Geometry) e L.o.l. (Level of Information) - in funzione degli obiettivi del modello, degli output di rappresentazione, e della fase progettuale in cui ci si trova (preliminare, definitiva, esecutiva).

Nella quarta fase, il modello BIM risultante dall'applicazione sui casi studio delle metodologie precedentemente descritte, recepisce e integra le informazioni relative a documentazione su interventi pregressi, materiali, componenti strutturali e sistemi tecnologici, e le aggrega rendendole accessibili, fruibili e interoperabili.

II modello in questo modo si configura come copia virtuale del costruito esistente e archivio di informazioni (documentali, diagnostiche, archivistiche, tecniche, ecc.) che spesso risultano difficilmente accessibili in una ispezione diretta o comunque generalmente disaggregate. II modello diventa lo strumento di lavoro e di confronto per tutti gli attori coinvolti nel processo, favorendo l'identificazione delle tecnologie da impiegare nel processo di riqualificazione e per la gestione delle fasi di cantiere, o dati per attività di monitoraggio.

Fig. 5. Flusso di lavoro basato sulla piattaforma $\mathrm{BIM}$, identificazione degli attori coinvolti intervento sull'esistente e rappresentazione delle principali catene di relazione.
BIM-DRIVEN WORKFLOW

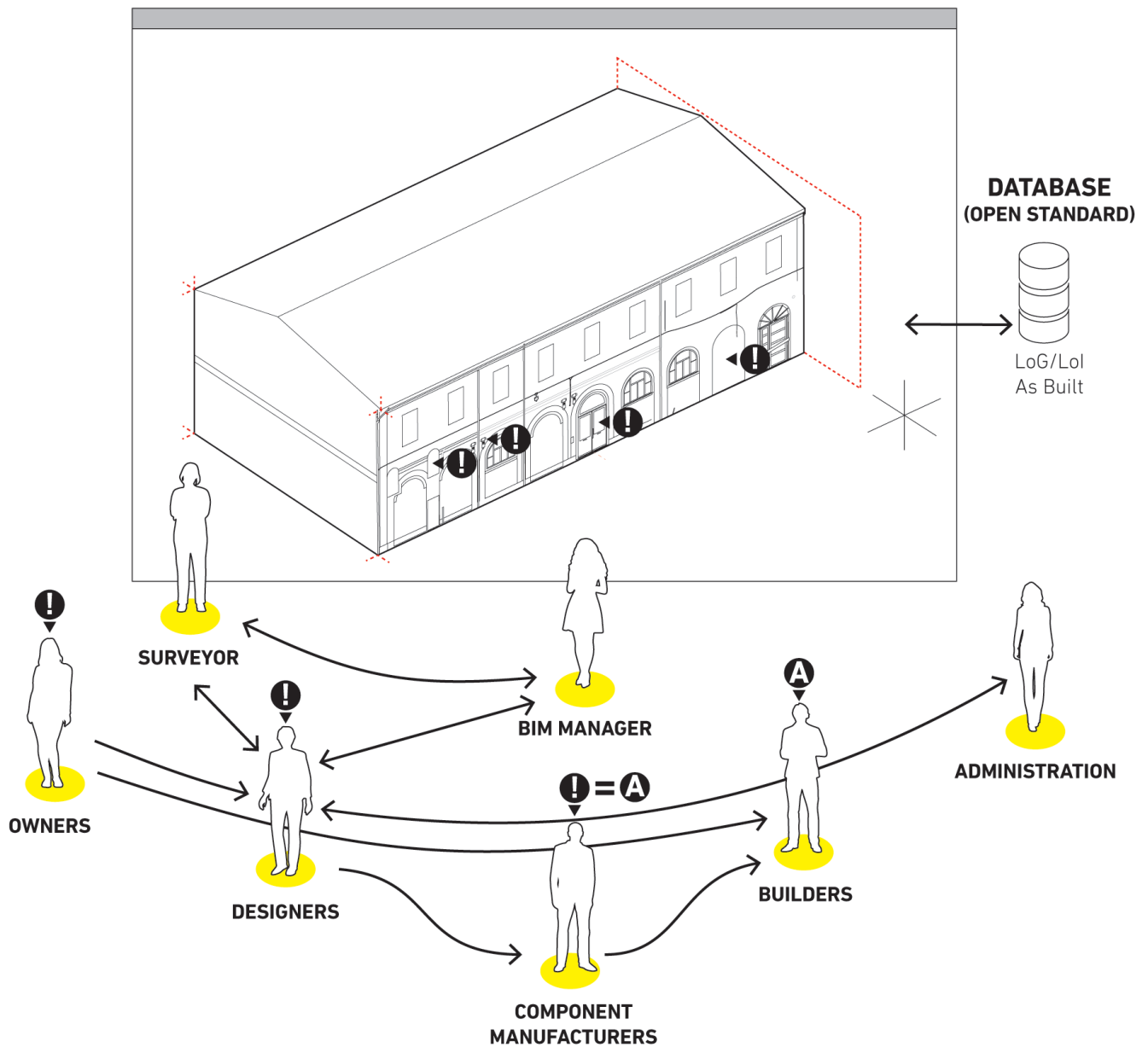

Dopo aver delineato le procedure ottimizzate di acquisizione dati e di modellazione BIM, i risultati attesi riguardano l'applicabilità di tali strumenti digitali, in particolare per quanto riguarda:

- creazione di archivi informatizzati e strutturati ad hoc, fruibili a tutti gli attori coinvolti, per la definizione di nuove soluzioni tecnologiche integrate;

- definizione di protocolli di intervento, di diagnostica e monitoraggio; 
- integrazione di strumenti e tecnologie ICT per la gestione interoperabile dei dati di progetto (strumenti BIM, strumenti ICT per l'integrazione del dato da rilievo integrato ai modelli descrittivi del progetto, strumenti per la valutazione degli scenari di progetto) [Osello et al. 20I5];

- avanzamento del formato standard IFC (Industry Foundation Class format) in grado di descrivere diversi dati e informazioni relative agli edifici del patrimonio esistente all'interno del processo BIM;

- creazione di soluzioni BIM che standardizzano soluzioni tecnologiche a problematiche ricorsive, o definiscono soluzioni custom per condizioni di intervento particolari.

Nel corso della ricerca, le procedure individuate vengono applicate e verificate su significativi casi studio, nelle fasi di acquisizione dati e modellazione con integrazione di tutte le informazioni rilevate nell'archivio informatizzato basato sui modelli BIM, al fine di proporre protocolli operativi di gestione dell'intervento sull'esistente.

\section{Conclusioni}

In materia di rappresentazione e gestione dei dati digitali, il BIM è oggi considerato l'ultima frontiera, essendo una metodologia in cui l'interoperabilità è uno degli attributi centrali. L'utilizzo della metodologia BIM sta diventando essenziale anche negli interventi sul costruito esistente, e negli interventi di conservazione e restauro [Chiabrando et al. 2019], grazie alla sua capacità di integrare informazioni e caratteristiche diverse in relazione alle forme geometriche del modello. Pertanto, esiste la necessità di collegare il rilievo e i processi di interpretazione dei dati con un avanzamento dell'IFC, in grado di descrivere e connettere diversi dati e informazioni relative agli edifici del patrimonio esistente all'interno del processo BIM. Da qui discende la centralità del tema della rappresentazione attraverso strumenti digitali in grado di connettere diversi saperi, diversi livelli informativi, e restituire in questo la complessità del processo di conoscenza e di progetto di intervento [Vernizzi 2017].

La ricerca ha quindi l'obiettivo di sviluppare da un lato una procedura ottimizzata, una metodologia in grado di sviluppare la modellazione BIM come "collettore" informativo di dati integrati a supporto dell'innovazione dell'intervento sul costruito esistente; dall'altro un'integrazione di strumenti digitali applicabili e replicabili su diversi segmenti del progetto, sviluppati a partire da casi studio in grado di restituire tutte le complessità dell'intervento sull'esistente.

In tale scenario, il progetto propone lo sviluppo di strumenti digitali in ambiente BIM applicati all'esistente per una migliore leggibilità del quadro degli interventi rigenerativi del patrimonio costruito regionale, la definizione di nuove soluzioni tecnologiche integrate e di protocolli di intervento e di monitoraggio.

A partire dalla strutturazione di banche dati accessibili finalizzate alla gestione dell'intervento nelle diversi fasi (documentazione, progetto, gestione, programmazione ecc.), in cui far convergere diversi livelli informativi (energetica, strutturale, ambientale ecc.), un possibile sviluppo futuro prevede l'integrazione dei modelli BIM in piattaforme multidisciplinari esistenti, che consentono ai diversi professionisti di lavorare in modo integrato e coordinato. L'avanzamento nell'applicazione degli strumenti BIM al patrimonio esistente, sulla base dell'evoluzione della normativa in corso e in vista della progressiva introduzione dell'obbligatorietà degli strumenti BIM, può contribuire in modo sostanziale alla definizione di strumenti operativi finalizzati alla riqualificazione del patrimonio esistente diffuso [2].

\section{Note}

[I] Si veda ad esempio il Documento S3 - Smart Specialization Strategy - Emilia-Romagna. Orientamenti innovativi per la strategia regionale di innovazione per la Smart Specialisation, Forum S3, giugno $2018<$ https://www.aster.it/pubblicazioni/orientamentiinnovativi-per-la-strategia-regionale-di-innovazione-per-la-smart?page=I, ultimo accesso II luglio 20|9; https://fesr.regione. emilia-romagna.it/s3, ultimo accesso 19 luglio 2019>, e i successivi rapporti di monitoraggio sullo stato di attuazione delle strategie regionali di ricerca e innovazione. 
22] La ricerca si inserisce nell'ambito del Dottorato di Ricerca IDAUP - Dottorato Internazionale Architettura \& Pianificazione Urbana, $35^{\circ}$ ciclo, consorziato tra I'Università degli Studi di Ferrara, Dipartimento di Architettura, la Polis University di Tirana e, come Associate Members, I'Università di Minho, Guimaraes (Portogallo), la Slovak University of Technology, Institute of Management, Bratislava (Slovacchia) e University of Pécs / Pollack Mihaly Faculty of Engineering and Information Technology (Ungheria). La ricerca è in corso di sviluppo grazie alla borsa finanziata dalla Regione Emilia-Romagna, bando Alte Competenze per la ricerca, il trasferimento tecnologico e l'imprenditorialità (Delibera di Giunta Regionale n. 39 del 14/0 I/2019), dal titolo: Applicazione di strumenti digitali integrati per il rilievo, la diagnostica e la modellazione BIM a supporto dellinnovazione di componenti e sistemi, prodotti e servizi ad alto valore aggiunto per l'intervento sul costruito esistente.

Borsa di dottorato approvata con la Deliberazione della G.R. n. 462/2019 "Approvazione dei progetti di formazione alla ricerca presentati a valere sull'Invito approvato con propria deliberazione n. 39/20 I9. POR FSE 20 I4/2020" Rif. PA 20। 9-II299/RER - CUP F75J19000440009.

\section{Riferimenti bibliografici}

Apollonio Fabrizio Ivan, Gaiani Marco, Bertacchi Silvia (2019). Managing Cultural Heritage with Integrated Services Platform. In ISPRS-International Archives of the Photogrammetry, Remote Sensing and Spatial Information Sciences, 42I I, pp. 91 I-98.

Bianchini Carlo (20I4). Survey, modeling, interpretation as multidisciplinary components of a Knowledge System. In SCIRES-ITSClentific RESearch and Information Technology, 4. I, pp. I5-24.

Bianchini Carlo, Inglese Carlo, Ippolito Alfonso (2016). II contributo della Rappresentazione nel Building Information Modeling (BIM) per la gestione del costruito. In DisegnareCon, 16, 9, pp. I 0. I - I0.9.

Bolognesi Cecilia Maria, Fiorillo Fausta (2019). The Integration of 3D Survey Technologies for an Accurate Reality-Based Representation: From Data Acquisition to BIM Modeling. In Conservation, Restoration, and Analysis of Architectural and Archaeological Heritage. IGl Global, pp. 32 I-345.

Brusaporci Stefano (ed.) (2019). Handbook of research on emerging digital tools for architectural surveying, modeling, and representation. In IGl Global, 2019 (2 voll.).

Chiabrando Filiberto, Lo Turco Massimiliano, Rinaudo Fulvio (2017). Modeling the decay in an HBIM starting from 3D point clouds. A followed approach for cultural heritage knowledge. In International Archives of the Photogrammetry, Remote Sensing \& Spatial Information Sciences, XLII-2NW5, pp. 605-612.

Djuedja Justine Flore Tchouanguem et al. (2019). Interoperability challenges in building information modelling (BIM). In AA.WV Enterprise interoperability VIII. Cham: Springer, pp. 275-282.

Fassi Francesco et al. (20I5). A New Idea of BIM System for Visualization, Web Sharing and Using Huge Complex 3D Models for Facility Management. In D. Gonzalez-Aguilera et al. (eds.). 6th International Workshop on 3D Virtual Reconstruction and Visualization of Complex Architectures, 3D-ARCH 20I5, pp. 359-366.

Gallozzi Arturo et al. (2019). An overview on Robotic Applications for Cultural Heritage and Built Cultural Heritage. In SCIRESIT-SClentific RESearch and Information Technology, 9(2), pp. 47-56.

Logothetis Sotirios et al. (20 I 8). Open source Cloud-based technologies for BIM. In International Archives of the Photogrammetry, Remote Sensing and Spatial Information Sciences, XLII-2, pp. 607-6I4.

López Facundo et al. (2018). A review of heritage building information modeling (H-BIM). In Multimodal Technologies and Interaction, 2(2), p. 21.

Olawumi Timothy O., Chan Daniel WM. (2019). Building information modelling and project information management framework for construction projects. In Journal of Civil Engineering and Management, 25( I), pp. 53-75.

Osello Anna et al. (20 I 6). The centrality of Representation with BIM. In Disegnarecon, vol. 9, n. I6, pp. 5. I-5. I 2.

Osello Anna et al. (20 I5). BIM and Interoperability for Cultural Heritage through ICT. In Brusaporci Stefano (ed.). Handbook of Research on Emerging Digital Tools for Architectural Surveying, Modeling, and Representation, IGI Global, pp. 28I-298.

Tommasi Cinzia et al. (2019). Access and Web-Sharing of 3D Digital Documentation of Environmental and Architectural Heritage. In 3D ARCH-3D Virtual Reconstruction and Visualization of Complex Architectures, vol. XLII-2MW, pp. 707-7I4.

Vernizzi Chiara (2017). II disegno tridimensionale di architettura, tra tradizione e innovazione, come espressione di creatività e strumento di prefigurazione e comunicazione dell'idea progettuale. In Antonella Di Luggo et al. (a cura di). Territori e Frontiere della Rappresentazione. Atti del 34 Convegno Internazionale dei Docenti della Rappresentazione. Napoli, I4-I6 settembre 2017, pp. 13-20. Roma: Gangemi Editore.

\section{Autori}

Federica Maietti, Università di Ferrara, federica.maietti@unife.it

Nicola Tasselli, Università di Ferrara, nicola.tasselli@unife.it

Per citare questo capitolo: Maietti Federica, Tasselli Nicola (2020). Connessioni digitali. Integrazione dati in ambiente BIM per l'intervento sul patrimonio esistente/Digital connections. Data integration in BIM environment for the intervention on existing buildings. In Arena A., Arena M., Brandolino R.G., Colistra D., Ginex G., Mediati D., Nucifora S., Raffa P. (a cura di). Connettere. Un disegno per annodare e tessere. Atti del $42^{\circ}$ Convegno Internazionale dei Docenti delle Discipline della Rappresentazione/Connecting. Drawing for weaving relationships. Proceedings of the 42th International Conference of Representation Disciplines Teachers. Milano: FrancoAngeli, pp. 585-598. 


\title{
Digital Connections. Data Integration in BIM Environment for the Intervention on Existing Buildings
}

\author{
Federica Maietti \\ Nicola Tasselli
}

\section{Abstract}

The paper is focused on the structuring of a methodological process of data acquisition and integration for the development of digital tools in BIM (Building information modeling) environment. This process is aimed at optimizing the digitalization processes to support the refurbishment, regeneration, maintenance and management of existing buildings. The scope of the research, currently underway and in its early stages of development, is limited to the existing heritage of the Emilia-Romagna region, and refers to the 'widespread' assets that needs to be upgraded in order to achieve current standards in terms of safety, energy efficiency, comfort, etc.

The integration of digital tools and the development of procedures in a parametric environment through the connection of multilayer information data, lead to the structuring of BIM models with high information value, integrated and accessible. A process that foresees digitization - from high information density survey to data modeling and sharing - as a possible answer to make the process more efficient.

Keywords

Building Information Modeling, existing heritage, representation, 3D survey, refurbishment.

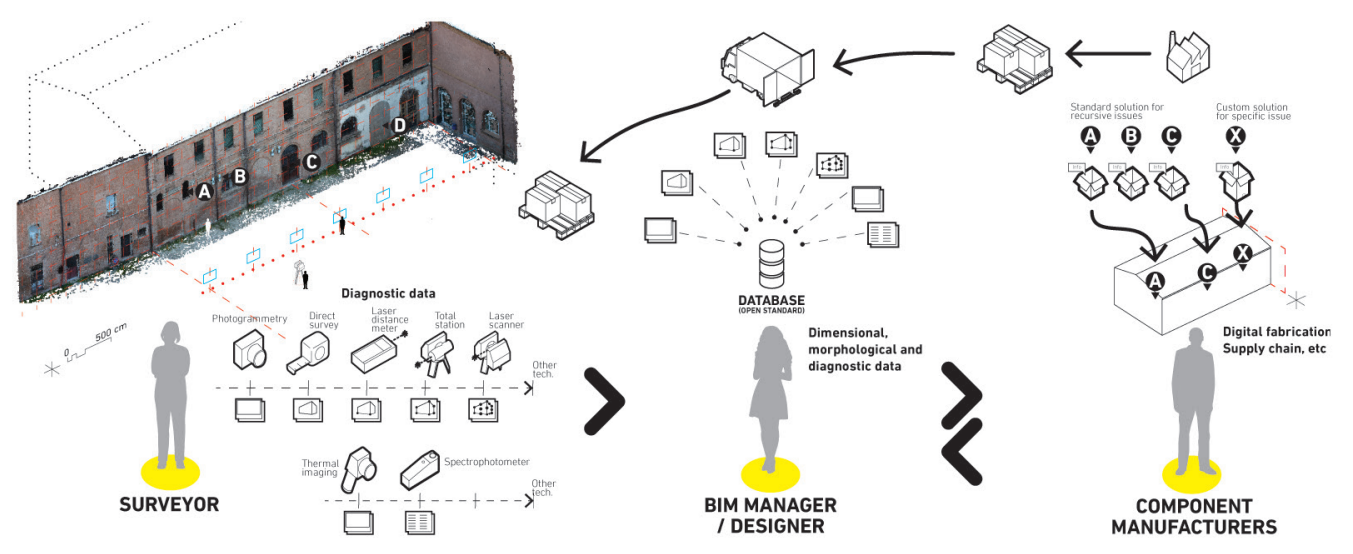




\section{Introduction}

This paper briefly summarizes a research that integrates different fields of the discipline of Drawing with strongly interdisciplinary topics related to one of the most pressing requirements in the current panorama: the conservation, upgrading and regeneration of existing heritage. The research field is limited, at territorial level, to the Emilia-Romagna region, starting from a series of priorities identified in monitoring reports [I] on the state of implementation of regional research and innovation strategies. These reports identify the redevelopment of existing heritage, urban regeneration, architectural quality, and technological, design and process innovation as central themes of the regional technological drivers.

The topic of the digitization of processes can be defined as a technological priority, where documentation, digital survey, modeling and data integration are increasingly necessary in the management of the intervention on existing heritage.

In this scenario, the research proposes to contribute to the development of digital tools in BIM environment aimed at a more efficient framework of regenerative interventions of the regional built heritage, the definition of new integrated technological solutions and intervention and monitoring protocols.

Two are the main objectives of the research. On the one hand, the optimization of the integrated digital survey to be applied to data documentation, acquisition, archiving, analysis, management and representation by defining a protocol in which the metric and morphological acquisition is integrated with all the information levels necessary for the management of the intervention on the existing built heritage.

On the other hand, the application of the Building Information Modeling (BIM) methodology to the existing building as a significant improvement of the process underlying the refurbishment interventions of the built heritage, through the creation of digital archives, to be used by the different actors involved in the process, towards the definition of new integrated technological solutions.

Fig. I. Schematic diagram of the integration between the phases of survey, design and implementation of the intervention on the built asset. The research aims at the definition of a protocol connecting the survey of the existing heritage to the integrated modeling in BIM environment.

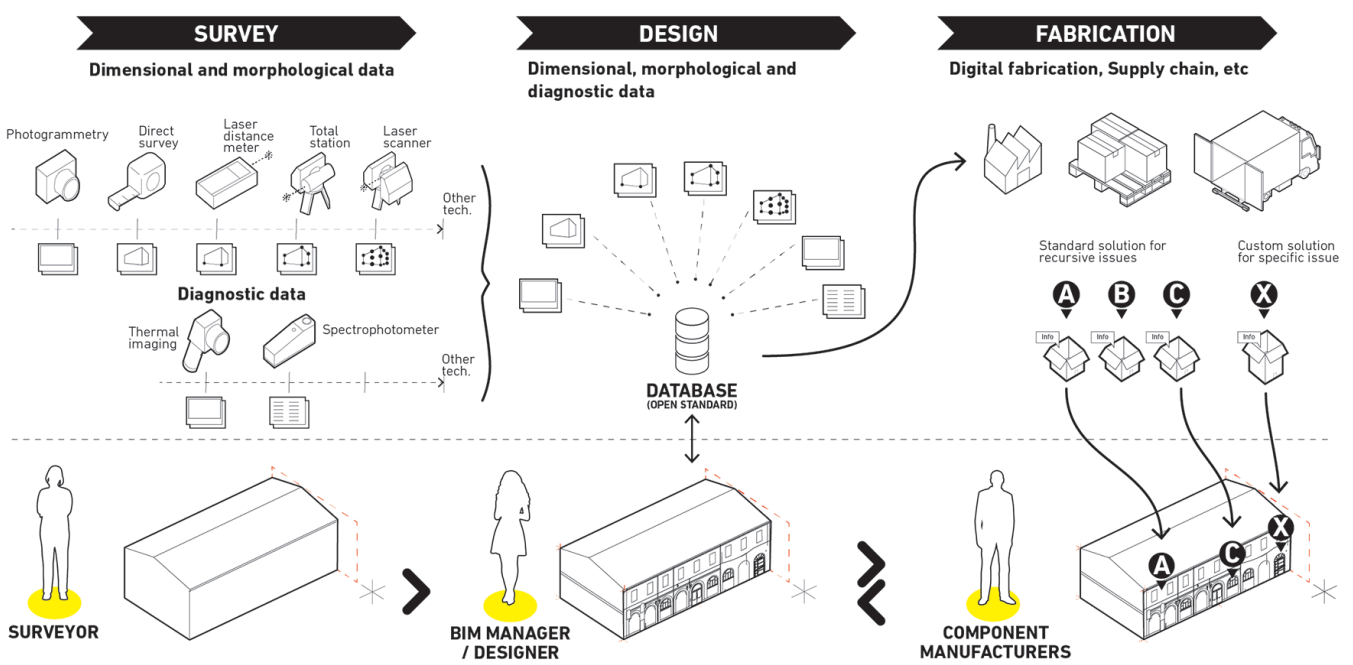

\section{Research field and state of the art}

The state of the art in the field of digitization of existing heritage [Bianchini 20 I 4; Brusaporci 20I9] and parametric modeling in BIM environment [Bianchini, Inglese, Ippolito 20 I6] is a rich and articulated panorama, in which research and different applications range in providing increasingly targeted contributions to the resolution of different critical issues [López et al. 20 I6; Bolognesi, Fiorillo 20 I9]. 
Among the essential areas of research for the conservation and enhancement of the built, historical and "widespread" heritage there are:

- the development of new survey and diagnostic technologies and the optimization of technologies for the rapid data acquisition [Gallozzi et al. 2019];

- the development of accessible databases for the documentation of the life cycle of the built environment [Apollonio et al. 2019; Tommasi et al. 20 I9];

- and, in general, the optimization, standardization and interoperability of processes in the direction of the integrated project.

In addition to a more efficient management of the built environment through integrated digital tools, the research aims to address the obsolescence of digital data (due to the lack of standardization) by promoting a more efficient use over time of the collected digital data and interoperability [Djuedja et al. 2019] between different systems (Open access data). On the one hand, the research aims to optimize the digitization of the existing building, on the other hand to respond to the fragmentation of the process and the inefficient use of data through parametric modeling, by integrating different information data (information obtained in the survey, analysis and documentation phase) in BIM models (both volumetric/ morphological and technological).

\section{Applied methodology}

The research is structured in four main areas. Starting from the definition of the state of the art, the optimization of an integrated survey protocol is developed. The protocol allows the acquisition and management of information according to the scale and complexity of the intervention [Fassi et al. 20 I5]. This step is connected to a critical analysis of the characteristics to be implemented in the management of survey information in a parametric BIM environment [Osello et al. 20 I 6] for the development of integrated data information tools/ packages to support the intervention on the existing building. The last phase provides for the application on case studies identified in the regional context, belonging to the existing heritage of the twentieth century characterized by levels of complexity useful to test the proposed digital tools.

Pursuing the main objective of fostering the development of information acquisition and management protocols (morphological and diagnostic) leading to the development of BIM tools to support the intervention project, the research is divided into four main phases.

The analysis of integrated survey methodologies, morphometric and diagnostic, and the development of data acquisition and management criteria are included the first phase, aimed at optimizing the acquisition procedures according to the specific needs of analysis and intervention on the built environment. In addition to metric-morphological survey procedures with high information density, the study of documentation and diagnostic survey tools that can be integrated in the data acquisition process is essential in order to obtain a model in which technological/conservative information are integrated with metric information. It is also foreseen the structuring of an archiving system of survey data and aggregated informa-

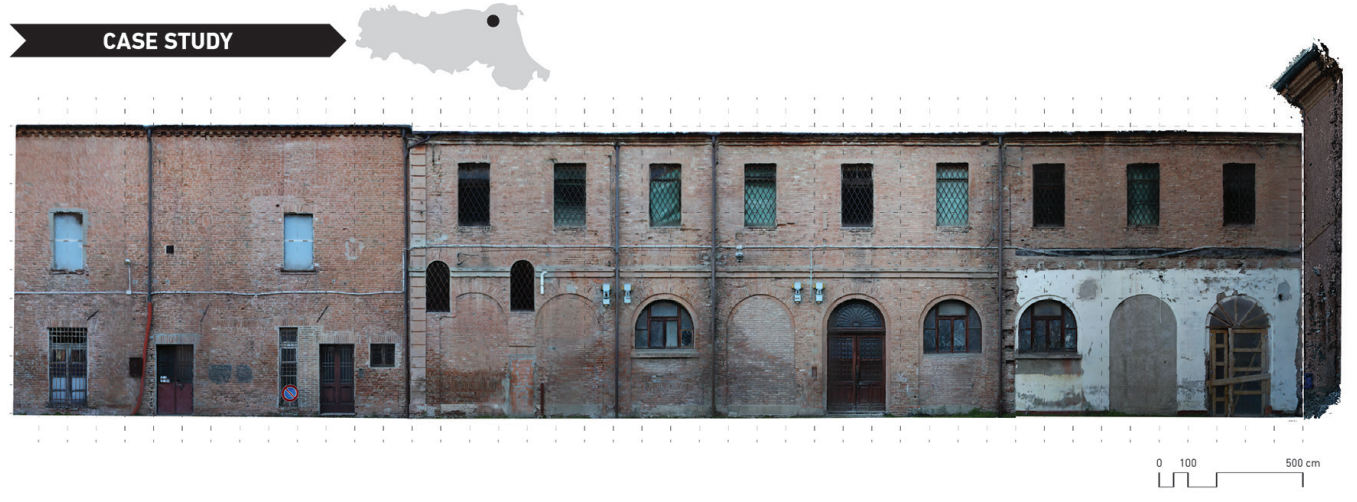




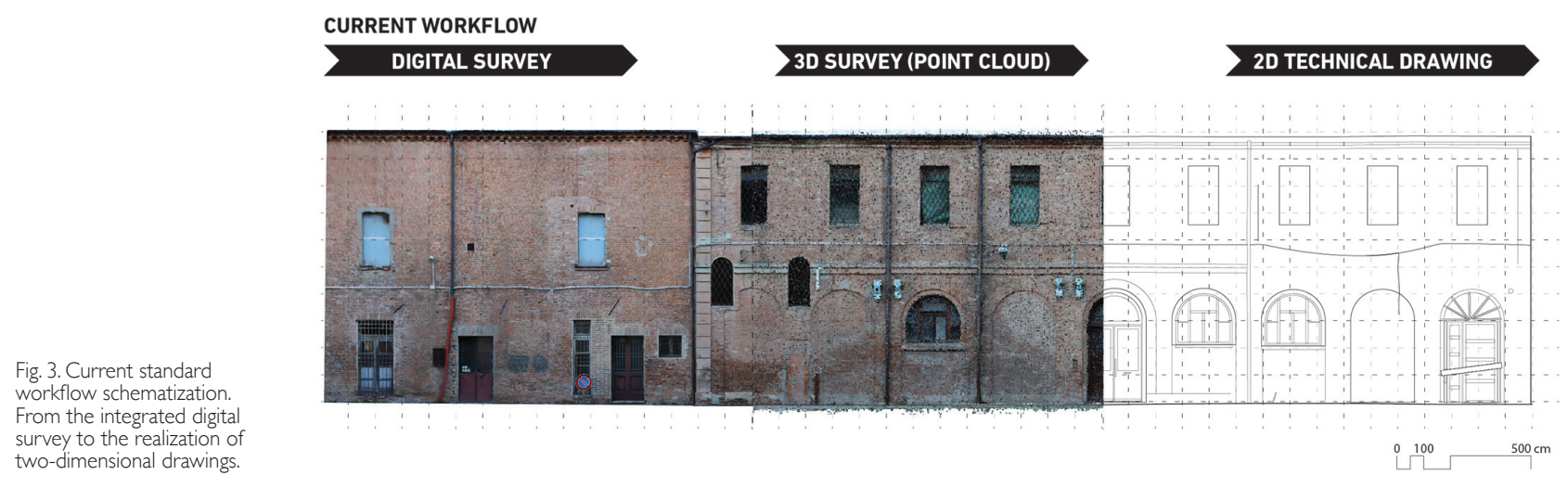

tion (material, state of conservation, documentation on previous interventions etc.) considering the different types of users involved in the intervention and aimed at structuring an integrated interoperable database [Logothetis et al. 20 I8].This data structuring methodology allows the integrated management of different information, keeping track of the source data in order to verify their accuracy.

The representation of the integrated three-dimensional survey aimed at BIM modeling requires optimization procedures able to manage and structure morphological and diagnostic information, managing different parameters (accuracy, precision, costs, time, data reliability, usability, etc.). This step is addressed in the second phase, which involves the definition of a data acquisition protocol aimed at producing an upgradable parametric information model. The protocol is set as a procedural guideline in which all the necessary information levels are integrated into the metric and morphological acquisition of the existing heritage. The protocol must ensure the integration and accessibility of the aggregated information in digital models, encouraging communication and collaboration between different professional

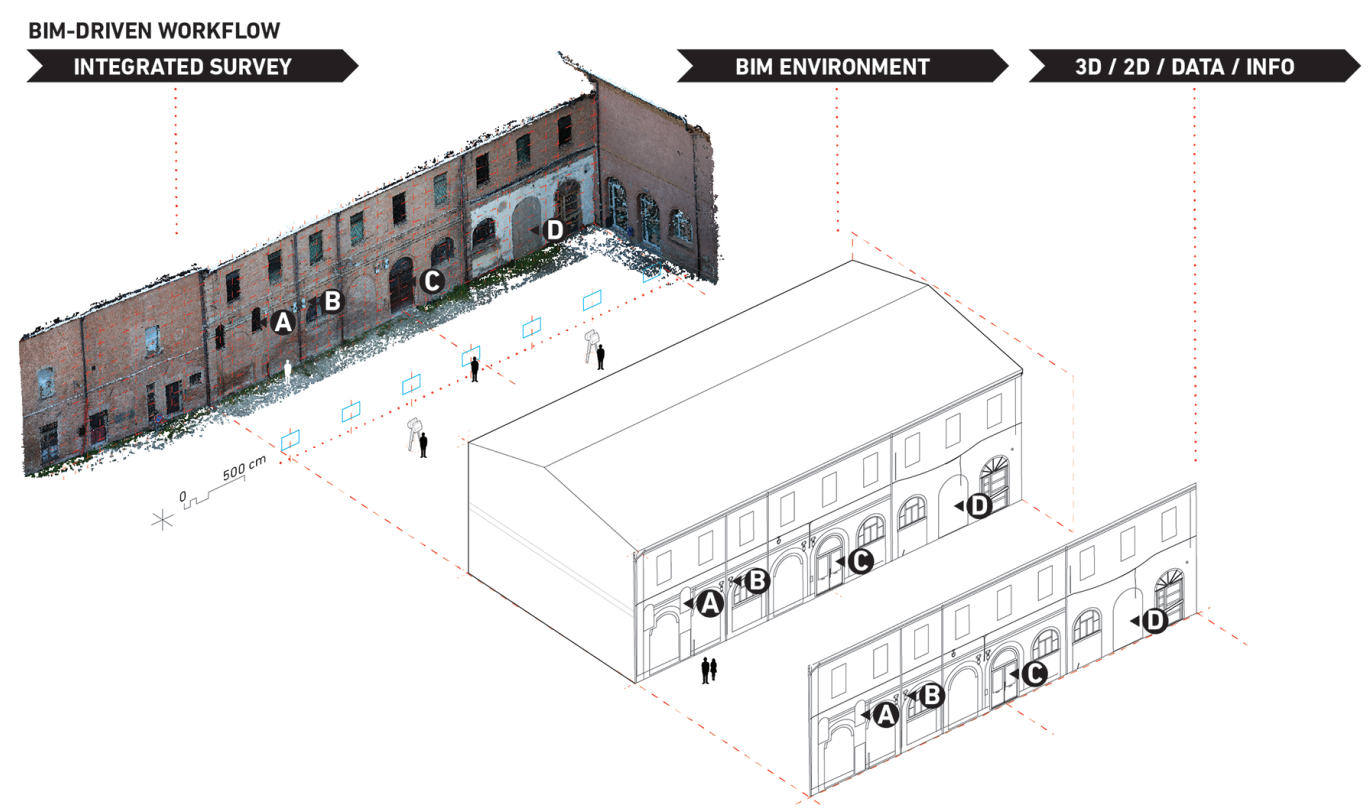

figures, identifying an optimal workflow for a coherent development of procedures for investigation and intervention on existing assets. The procedures defined through the protocol must interact and integrate with current software solutions, encouraging the effective use of the acquired data and integrated information and the protocol that discretizes them.

The data acquisition procedure through the protocol is aimed at BIM modeling, defining a workflow able to optimize the acquisition based on the characteristics / information levels 
needed [Olawumi et al. 2019] according to the set objectives. Starting from the survey, the third phase is therefore focused on the definition of methodologies and procedures for parametric modeling, developing a procedure in which all information related to geometry are integrated with additional information. These information can be related to materials, implementation phases, costs, technical characteristics, etc. The building is therefore related to environmental factors, defining the L.O.D. (Level of Detail) - L.o.G. (Level of Geometry) and L.o.l. (Level of Information) - according to the objectives of the model, the representation outputs, and the specific design stage (preliminary, definitive, executive).

Within the fourth phase, the BIM model resulting from the application on case studies of the methodologies described above, includes and integrates the information related to documentation on past interventions, materials, structural components and technological systems, and aggregates them making this information accessible, usable and interoperable. In this way, the model is set as a virtual copy of the existing building and archive of information (documentary, diagnostic, archival, technical, etc.) that is often difficult to access in a direct inspection or that are generally disaggregated. The model becomes the working and comparison tool for all the actors involved in the process, fostering the identification of the

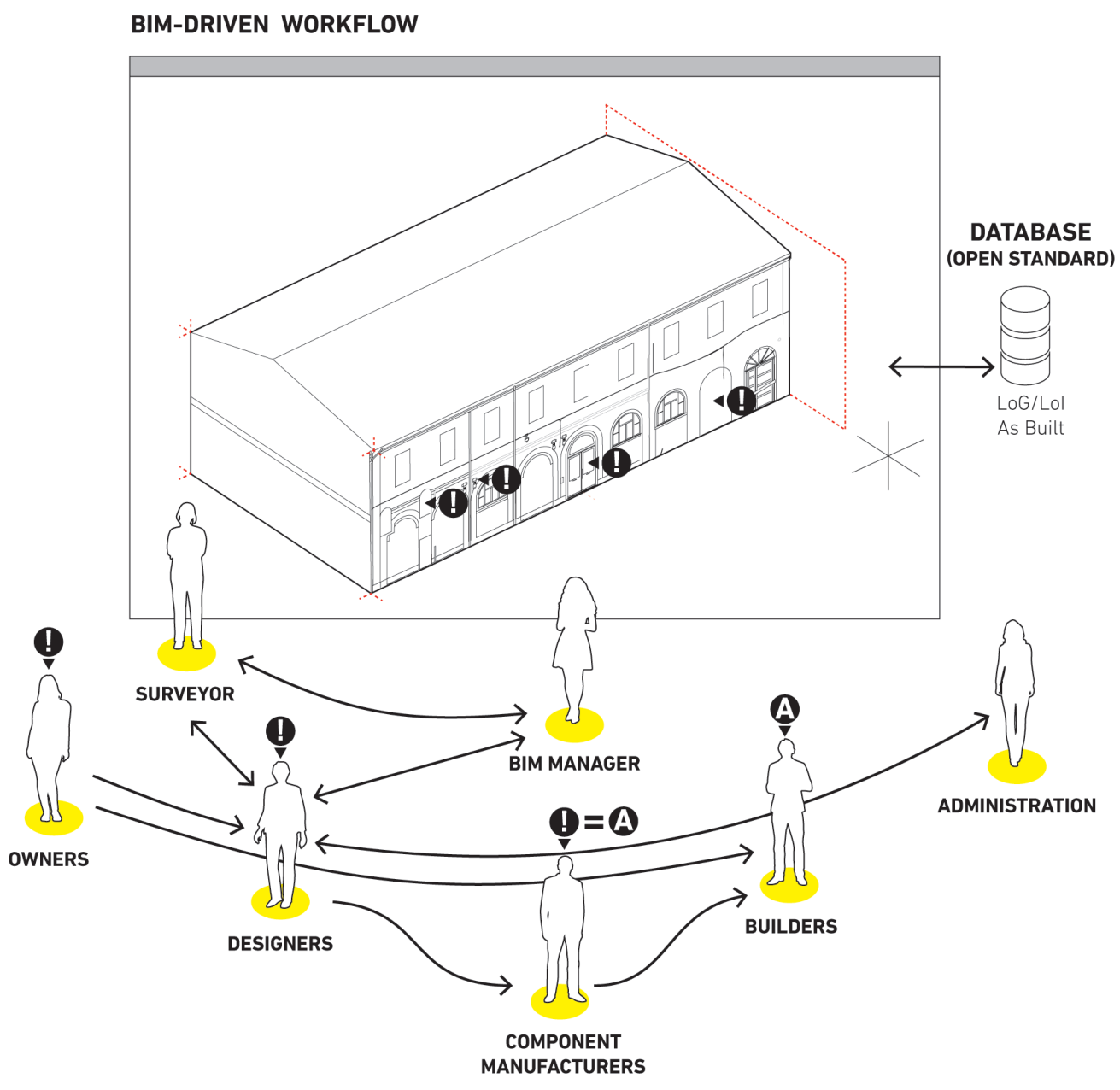

technologies to be used in the requalification process and for the management of the site phases, or data for monitoring activities.

After outlining the optimized data acquisition and BIM modeling procedures, the expected results concern the applicability of these digital tools, in particular with regard to the:

- creation of specific structured digital archives, usable by all the actors involved, for the definition of new integrated technological solutions;

- definition of intervention, diagnostic and monitoring protocols; 
- integration of ICT tools and technologies for the interoperable management of project data (BIM tools, ICT tools for the integration of survey data integrated with project descriptive models, tools for the evaluation of project scenarios) [Osello et al. 20 I5];

- advancement of the Industry Foundation Class (IFC) standard format able to describe different data and information related to existing heritage buildings within the BIM process; - creation of BIM solutions that standardize technological answers to recursive problems or define custom solutions for particular intervention conditions.

During the research, the procedures identified are applied and tested on significant case studies, from data acquisition up to modeling with integration of all the information surveyed. Digital archives based on BIM models are the support to propose operational protocols for the management of the intervention on existing heritage.

\section{Conclusions}

In the field of digital data representation and management, BIM is today considered the last frontier, being a methodology where interoperability is one of the central attributes.

The use of the BIM methodology is also becoming essential in existing building interventions, and in conservation and restoration interventions [Chiabrando et al. 20 I9], thanks to its ability to integrate different information and characteristics in relation to the geometric shapes of the model. Therefore, there is a need to link the survey and data interpretation processes with an advancement of the IFC, able to describe and connect different data and information related to existing heritage buildings within the BIM process.

From this comes the centrality of the topic of representation through digital tools able to connect different knowledge, different levels of information, and representing the complexity of the process of knowledge and intervention project [Vernizzi 2017].

The research therefore aims to develop, on one hand, an optimized procedure, a methodology able to develop BIM modeling as an information "collector" of integrated data to support the innovation of the intervention on the existing built. On the other hand, an integration of digital tools applicable and replicable on different sections of the project, developed starting from case studies able to provide all the complexities of the intervention on existing buildings.

In this scenario, the project proposes the development of digital tools in BIM environment for a better readability of the framework of the regenerative interventions of the regional built heritage, the definition of new integrated technological solutions and of protocols for intervention and monitoring.

Starting from the structuring of accessible databases aimed at managing the intervention in the different phases (documentation, project, management, programming, etc.), in which different information levels (energy, structural, environmental, etc.) converge, a possible future development foresees the integration of BIM models in existing multidisciplinary platforms, allowing different professionals to work in an integrated and coordinated way.

The progress in the application of BIM tools to the existing heritage, based on the evolution of the current legislation and in view of the progressive introduction of the mandatory nature of BIM tools, can contribute substantially to the definition of operational tools aimed at the redevelopment of the existing widespread heritage

\section{Notes}

[I] See Document "S3 - Smart Specialization Strategy - Emilia-Romagna. Innovative Guidelines for the Regional Innovation Strategy for Smart Specialisation, Forum S3 - June $2018<$ https://www.asterit/pubblicazioni/orientamenti-innovativi-per-la-strategiaregionale-di-innovazione-per-la-smart?page = I, last accessed I I July 20 I 9; https://fesr.regione.emilia-romagna.it/s3, last accessed 19 July $2019>$, and following monitoring reports on the state of implementation of regional research and innovation strategies..

[2] The research is part of the IDAUP - International Doctorate in Architecture \& Urban Planning, 35th cycle, consortium between the University of Ferrara, Department of Architecture, Polis University of Tirana and, as Associate Members, the University of Minho, Guimaraes (Portugal), Slovak University of Technology, Institute of Management, Bratislava (Slovakia) and University of Pécs / Pollack Mihaly Faculty of Engineering and Information Technology (Hungary). The research is being developed thanks to the grant funded by the Emilia-Romagna Region. Call Alte Competenze per la ricerca, il trasferimento tecnologico e l'imprenditorialità (Delibera di Giunta Regionale n. 39 del I4/0 I/20 I 9), entitled:Application of integrated digital 
tools for surveying, diagnostics and BIM modelling to support innovation of components and systems, products and services with high added value for the intervention on existing buildings.

Doctoral fellowship approved by the Deliberation of the G.R. n. 462/2019 "Approval of the research training projects presented on the basis of the Call approved by its own resolution n. 39/20 I9. POR FSE 20 I 4/2020" Ref. PA 20 I9-I I 299/RER - CUP F75] 19000440009.

\section{References}

Apollonio Fabrizio Ivan, Gaiani Marco, Bertacchi Silvia (2019). Managing Cultural Heritage with Integrated Services Platform. In ISPRS-International Archives of the Photogrammetry, Remote Sensing and Spatial Information Sciences, 42 I I, pp. 9 I -98.

Bianchini Carlo (20I4). Survey, modeling, interpretation as multidisciplinary components of a Knowledge System. In SCIRES-ITSClentific RESearch and Information Technology, 4. I, pp. I5-24.

Bianchini Carlo, Inglese Carlo, Ippolito Alfonso (20 I6). II contributo della Rappresentazione nel Building Information Modeling (BIM) per la gestione del costruito. In DisegnareCon, 16, 9, pp. I0.1-10.9.

Bolognesi Cecilia Maria, Fiorillo Fausta (2019). The Integration of 3D Survey Technologies for an Accurate Reality-Based Representation: From Data Acquisition to BIM Modeling. In Conservation, Restoration, and Analysis of Architectural and Archaeological Heritage. IGl Global, pp. 32 I-345.

Brusaporci Stefano (ed.) (2019). Handbook of research on emerging digital tools for architectural surveying, modeling, and representation. In IGI Global, 2019 (2 voll.).

Chiabrando Filiberto, Lo Turco Massimiliano, Rinaudo Fulvio (2017). Modeling the decay in an HBIM starting from 3D point clouds. A followed approach for cultural heritage knowledge. In International Archives of the Photogrammetry, Remote Sensing \& Spatial Information Sciences, XLII-2/W5, pp. 605-6I2.

Djuedja Justine Flore Tchouanguem et al. (2019). Interoperability challenges in building information modelling (BIM). In AA.VV. Enterprise interoperability VIII. Cham: Springer, pp. 275-282.

Fassi Francesco et al. (20I5). A New Idea of BIM System for Visualization, Web Sharing and Using Huge Complex 3D Models for Facility Management. In D. Gonzalez-Aguilera et al. (eds.). 6th International Workshop on 3D Virtual Reconstruction and Visualization of Complex Architectures, 3D-ARCH 20 I5, pp. 359-366.

Gallozzi Arturo et al. (2019). An overview on Robotic Applications for Cultural Heritage and Built Cultural Heritage. In SCIRESIT-SClentific RESearch and Information Technology, 9(2), pp. 47-56.

Logothetis Sotirios et al. (20 I 8). Open source Cloud-based technologies for BIM. In International Archives of the Photogrammetry, Remote Sensing and Spatial Information Sciences, XLII-2, pp. 607-6I4.

López Facundo et al. (2018). A review of heritage building information modeling (H-BIM). In Multimodal Technologies and Interaction, 2(2), p. 21.

Olawumi Timothy O., Chan Daniel WM. (2019). Building information modelling and project information management framework for construction projects. In Journal of Civil Engineering and Management, 25(I), pp. 53-75.

Osello Anna et al. (20 I6). The centrality of Representation with BIM. In Disegnarecon, vol. 9, n. I6, pp. 5. I-5. I2.

Osello Anna et al. (20 I5). BIM and Interoperability for Cultural Heritage through ICT. In Brusaporci Stefano (ed.). Handbook of Research on Emerging Digital Tools for Architectural Surveying, Modeling, and Representation, IGI Global, pp. 28 I-298.

Tommasi Cinzia et al. (2019). Access and Web-Sharing of 3D Digital Documentation of Environmental and Architectural Heritage. In 3D ARCH-3D Virtual Reconstruction and Visualization of Complex Architectures, vol. XLII-2M9, pp. 707-7I4.

Vernizzi Chiara (2017). Il disegno tridimensionale di architettura, tra tradizione e innovazione, come espressione di creatività e strumento di prefigurazione e comunicazione dell'idea progettuale. In Antonella Di Luggo et al. (a cura di). Territori e Frontiere della Rappresentazione. Atti del $34^{\circ}$ Convegno Internazionale dei Docenti della Rappresentazione. Napoli, I4- 16 settembre 2017, pp. I3-20. Roma: Gangemi Editore.

\section{Authors}

Federica Maietti, Università di Ferrara, federica.maietti@unife.it Nicola Tasselli, Università di Ferrara, nicola.tasselli@unife.it

To cite this chapter. Maietti Federica, Tasselli Nicola (2020). Connessioni digitali. Integrazione dati in ambiente BIM per l'intervento sul patrimonio esistente/Digital connections. Data integration in BIM environment for the intervention on existing buildings. In Arena A., Arena M., Brandolino R.G., Colistra D., Ginex G., Mediati D., Nucifora S., Raffa P. (a cura di). Connettere. Un disegno per annodare e tessere. Atti del $42^{\circ}$ Convegno Internazionale dei Docenti delle Discipline della Rappresentazione/Connecting. Drawing for weaving relationships. Proceedings of the 42th International Conference of Representation Disciplines Teachers. Milano: FrancoAngeli, pp. 585-598. 